Jurnal Indonesia Sosial Teknologi:p-ISSN: 2723 - 6609

e-ISSN :2745-5254

Vol. 2, No.12 Desember 2021

\title{
PENGEMBANGAN SISTEM INFORMASI TASK MANAJEMEN BERBASIS ANDROID DI ORION IT SOLUTION
}

\section{Gunawan Wirasatya Putra}

Program Studi Manajemen Informatika, Politeknik Piksi Ganesha Bandung

Email: gunawan10posadas@gmail.com

\begin{abstract}
Abstrak
Orion IT Solution bergerak dalam perancangan dan pembuatan aplikasi. Seiring dengan kesuksesan dalam bidang tersebut maka pimpinan Orion IT Solution akan menyiapkan aplikasi tambahan untuk menangani 2 sampai 3 aplikasi yang harus dikerjakan dalam waktu bersamaan. Sistem informasi untuk mengelola tersebut telah dibuat oleh pimpinan tetapi masih dalam bentuk aplikasi desktop dan hanyamengatur proses bisnis untuk internal saja. Metode yang penulis gunakan ialah metode RAD. Penulis telah menganalisa sistem yang sudah ada dan akan mengembangkan sistem informasi tersebut dengan menambahkan fitur penginputan task manajemen secara online yang dapat dilakukan oleh pegawai secara realtime. Terdapat fitur penginputan task manajemen dan laporan task manajemen. Fitur tersebut akan memberikan dampak positif yang besardalam membantu kelancaran dan kecepatan pada proses bisnis ini.Dengan adanya fitur andorid pegawai dan pimpinan dapat melihat dan mengerjakan pekerjaan dimana saja tanpa perlu repot bekerja di kantor.
\end{abstract}

Kata kunci: Pengembangan; Aplikasi; Android; RAD.

\begin{abstract}
Orion IT Solution is engaged in application design and development. Along with success in this field, the leadership of Orion IT Solution will prepare additional applications to handle 2 to 3 applications that must be done at the same time. The management information system has been created by the leadership but is still in the form of a desktop application and only manages internal business processes. The method that the author uses is the RAD method. The author has analyzed the existing system and will develop the information system by adding an online task management input feature that can be done by employees in real time. There are task management inputting features and task management reports. These features will have a big positive impact in helping smooth and speed up this business process.
\end{abstract}

Keywords: Development; Application; Androids; RAD.

\section{Pendahuluan}

Teknologi informasi dan komunikasi semakin berkembang pesat saat ini. Teknologi internet mempunyai pengaruh yang cukup besar dalam segala bidang khususnya dalam hal melihat catatan pekerjaan bagi suatu perusahaan (Sutarman, 2012). 
Terdapat kemudahan dari sisi pegawai seperti hanya dengan dari rumah atau dimana pun berada, mengakses informasi dan melihat catatan pekerjaan secara online.

Orion IT Solution adalah perusahaan yang telah lama bergerak dibidang IT, khususnya dalam pembuatan aplikasi atau software yang telah berdiri sejak tahun 2003 . Sejauh ini Orion IT Solution sudah terbiasa dalam menangani perancangan dan pembuatan aplikasi yang berbasis desktop, android ataupun website.

Seiring dengan keinginan berkembangnya perusahaan tersebut, pimpinan Orion IT akan mengembangkan task manajemen. Aplikasi sistem pengelolaan task manajemen sudahdikembangkan oleh tim internal diperusahaan tersebut (Hidayat \& Machali, 2012). Sistem yang ada sudah mencakup dari Input pekerjaan, dan laporan-laporan. Sistem tersebut masih dalam tahap pengembangan dan hanya mengelola pada sisi internal saja.

Setelah penulis melakukan analisis pada sistem yang sudah ada, penulis memiliki kesimpulan untuk mengembangkan aplikasi tersebut dengan menambah fitur penginputan task manajemen secara online dan dapat langsung dilakukan oleh pegawai pada smartphone masing-masing (Muhammad Roby \& Akhmad, 2019). Fitur tersebut akan sangat membantu untuk pimpinan dan pegawai, proses task manajemen akan lebih cepat dilakukan.

Tidak terbatas hanya untuk taks manajemen, aplikasi hasil pengembangan penulis pun akan menyediakan beberapa fitur histori pekerjaan, dan lainnya (Runtuwene, 2016). Dengan begitu pegawai dan pimpinan akan mendapatkan data yang selalu terupdate tentang pekerjaan sudah di tambahkah oleh pimpinan Orion IT Solution ini.

Alasan penulis memakai platform android tidak lain karena banyak sekali dukungan dari berbagai vendor serta kemudahan yang dimilikinya (Adani, 2020a). Aplikasi dapat diakses dimanapun, karena system ini dibangun pada platform Android yang memiliki market share sebesar 71,93\% secara global (O'Dea, 2021). Untuk data yang diperoleh dari aplikasi desktop penulis menggunakan API karena lebih memudahkan dalam mengaksesnya (Adani, 2020). Database yang digunakan adalah MySql tidak lain karena mendukung penggunaan multi user (Adani, 2020) dan banyak lagi kelebihan lainnya.

Berikut merupakan tinjauan kembali dari pustaka yang penulis peroleh dan penulis jadikan dasar penelitian saat ini, yaitu: 1. Task Manajemen merupakan aktivitas atau proses identifikasi, merencanakan, visualisasi, memonitor, dan mengevaluasi sebuah pekerjaan dalam satu periode waktu. Biasanya dalam melakukan aktivitas tersebut, pertama-tama Anda akan melakukan identifikasi pekerjaan mana yang sifatnya penting dan segera. 2. Perancangan atau rancang merupakan serangkaian prosedur untuk menterjemahkanhasil analisa dan sebuah sistem ke dalam bahasa pemrograman untuk mendeskripsikan dengan detail bagaimana komponen-komponen sistem di implementasikan (Pressman, 2005). 3. Sistem adalah Sekelompok elemen-elemenyang terintegrasi dengan tujuan yang sama untuk mencapai tujuan (Tashia, 2017). 4. Android studio adalah IDE (Integrated Development Environment) resmi untuk pengembangan aplikasi Android dan bersifat open source atau gratis. Peluncuran Android Studio ini 
diumumkan oleh Google pada 16 mei 2013 pada event Google I/O Conference untuk tahun 2013. Sejak saat itu, Android Studio mengantikan Eclipse sebagai IDE resmiuntuk mengembangkan aplikasi Android (Juansyah, 2015). Dengan pembuatan Task Manajemen secara android, pegawai dan pimpinan dapat melihat dan mengerjakan pekerjaan lebih efisien, karena bisa di kerjakan dimana saja tanpa perlu bekerja di kantor.

\section{Metode Penelitian}

Tahap penelitian dimulai dari pendahuluan yang meliputi latar belakang, identifikasi masalah, rumusan masalah, batasan masalah serta tujuan dan manfaat penelitian. Tahap ini juga merupakan tahapawal dalam metodologi pengembangan sistem model Rapid Apllication Development (RAD) sebagai tahap untuk mendefinisikan persyaratan - persyaratan.

Perancangan aplikasi ini dilakukan menggunakanmetode RAD karena metode ini mempunyai keunggulan dibanding metode konvensional lainya (Noertjahyana, 2002), seperti kecepatan, ketepatan serta biaya yang relatif lebih murah. Metode ini digunakan juga mempertimbangkan aplikasi ini akan memiliki update fitur sesuai dengan kebutuhan kedepanya menjadi akan lebih mudah.

Tahap berikutnya yaitu pengumpulan data, dalam pengumpulan data ada tiga teknik yang di gunakan yaitu observasi, wawancara dan studi literatur. Kemudian di lanjutkan dengan tahap desain workshop dan implementasi. Sampai dengan tahap terakhir yaitu penutup yang bersisi kesimpulan dan saran (Pressman, 2012).

Metode RAD bertujuan mempersingkat waktu yang biasanya diperlukan dalam siklus hidup pengembangan sistem tradisional antaraperancangan dan penerapan suatu sistem informasi. Pada akhirnya, RAD sama-sama berusaha memenuhi syarat-syarat bisnis yang berubah secaracepat.

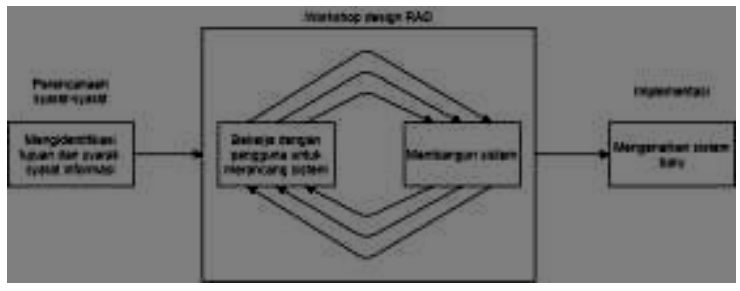

Gambar 1. Siklus RAD

Berikut ini adalah tahap-tahap pengembangan aplikasi dari tiap-tiap fase pengembangan aplikasi (Kendall, 2010).

a. Requirements Planning (Perencanaan Syarat- Syarat)

Dalam fase ini, pengguna dan penganalisis bertemu untuk mengidentifikasikan tujuan - Registrasi Login tujuan aplikasi atau sistem serta untuk megidentifikasikan syarat-syarat informasi yang ditimbulkan dari tujuan-tujuan tersebut.

Orientasi dalam fase ini adalah menyelesaikan masalah-masalah perusahaan. Meskipun teknologi informasi dan sistem bisa mengarahkan sebagian dari sistem yang diajukan, fokusnya akan selalu tetap pada upaya pencapaian tujuan-tujuan perusahaan.

b. RAD Design Workshop (Workshop Desain RAD) 
Fase ini adalah fase untuk merancang danmemperbaiki yang bisa digambarkan sebagaiworkshop. Penganalisis dan dan pemrogram dapat bekerja membangun dan menunjukkan representasi visual desain dan pola kerja kepada pengguna. Workshop desain ini dapatdilakukan selama beberapa hari tergantung dariukuran aplikasi yang akan dikembangkan.

Selama workshop desain RAD, pengguna merespon prototipe yang ada dan penganalisis memperbaiki modul-modul yang dirancangberdasarkan respon pengguna. Apabila sorang pengembangnya merupakan pengembang atau pengguna yang berpengalaman, Kendall menilai bahwa usaha kreatif ini dapat mendorong pengembangan sampai pada tingkatterakselerasi.

c. Implementation (Implementasi)

Pada fase implementasi ini, penganalisis bekerja dengan para pengguna secara intens selama workshop dan merancang aspek-aspek bisnis dan nonteknis perusahaan. Segera setelah aspek-aspek ini disetujui dan sistemsistem dibangun dan disaring, sistemsistem baru atau bagian dari sistem diujicoba dan kemudian diperkenalkan kepada organisasi.

\section{Hasil dan Pembahasan \\ Perancangan Sistem}

Sistem yang dibuat merupakan usulan perancangan sistem untuk mengembangkan task yang sedang berjalan sebelumnya. Maka solusi yang diusulkan adalah dengan membuat sistem informasi Task Management berbasis Android, sistem informasi ini akan memuat fasilitas yang dibutuhkan sebagai berikut :

1. Kemudahan distribusi pekerjaan, memungkinkan para pemimpin memberikan task kepada timnya melalui sistem informasi Task Management.

2. Kemudahan pelaporan pekerjaan, memungkinkan anggota tim melaporkan hasil pekerjaan nya melalui sistem informasi Task Management.

3. Kemudahan monitoring progress plan, memungkinkan pimpinan dan pihak manajemen lainnya untuk memantau progress plan.

4. Analisa dan Evaluasi, dengan visualisasi dalam bentuk grafik maka sistem dapat memberikan informasi yang berguna untuk kebutuhan analisa dan evaluasi.

Analisa disini mencakup analisa progress suatu plan dan juga analisa sumber daya manusia, sehingga dari hasil analisa tersebut pihak menajemen dapat memberikan evaluasi kepada tim nya.

\section{Perancangan Prosedur Yang Diusulkan}

Perancangan yang diusulkan ini meliputi use case diagram, class diagram, dan program yang dapat menghasilkan sebuah sistem yang lebih baik. Proses yang dirancang dan diuraikan menjadi beberapa bagian yang dapat membentuk sistem tersebut menjadi satu kesatuan komponen.

\section{Use Case Diagram}




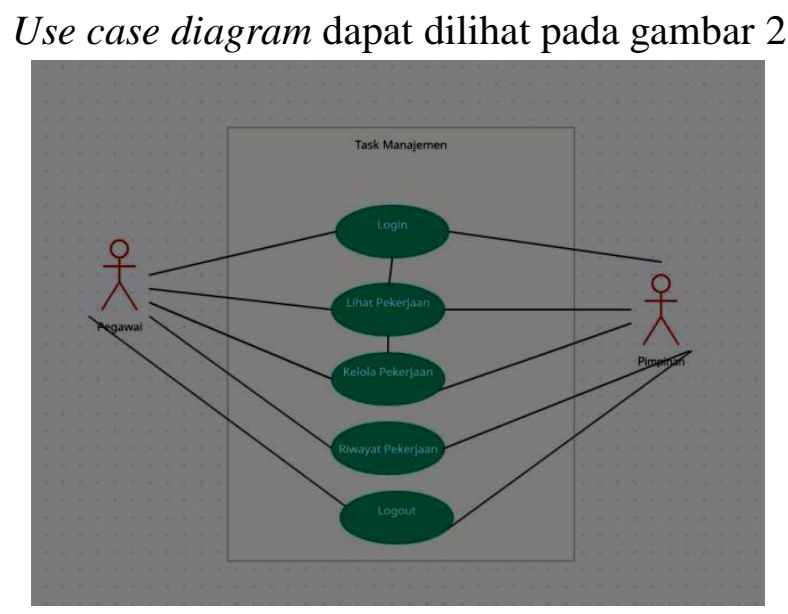

Pada usecase diagram tersebut, ada 2 aktor didalamnya yaitu pimpinan dan pegawai, pada aplikasi yang penulis kembangkan, pegawai dapat melakukan beberapa aksi diawali dengan login lalu dapat mengakses lihat pekerjaan, input pekerjaan, dan riwayat pekerjaan. Untuk pegawia mengelola data pekerjaan berada dalam cakupan aplikasi desktop dalam aplikasi yang sudah ada sebelumnya.

\section{Class Diagram}

Dalam class diagram ini menjelaskan tentang struktur sistem dari segi pendefinisian kelas - kelas yang akan dibuat untuk membangun sistem tersebut.

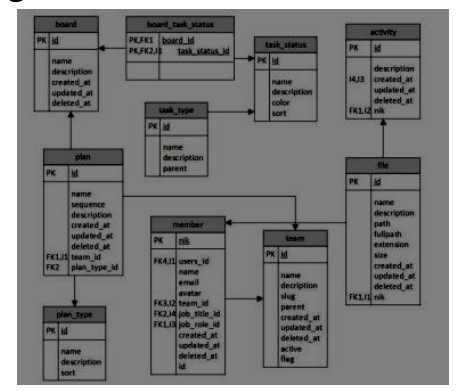

Gambar 3. Class diagram

Class diagram menggambarkan design table yang dibuat untuk aplikasi yang penulis rancang. Disini terlihat relasi-relasi antar class yang telah penulis buat.

\section{Tampilan Aplikasi}

Berikut merupakan tampilan aplikasi yang penulis telah dibuat:

1. Login

Berikut adalah tampilan dari form login, pegawai (user) diharuskan mengisi username dan password yang sudah didaftarkan sebelumnya oleh pegawai untuk mengakses keseluruhan fitur pada aplikasi ini. 
Gunawan Wirasatya Putra

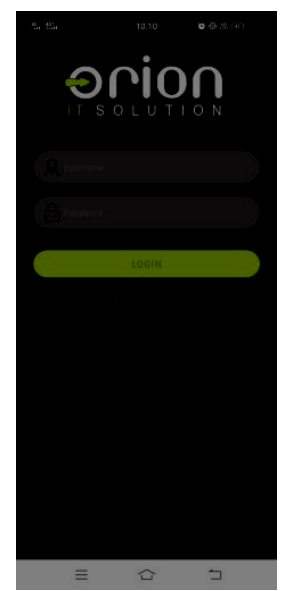

Gambar 4. Login Form

2. Beranda

Dibawah ini merupakan tampilan beranda, ada fitur search pada bagian atas dan beberapa menu yang dapat user akses langsung.

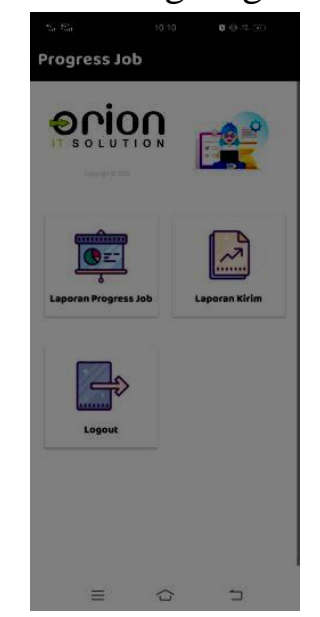

\section{Gambar 5. Beranda}

\section{Gambar 5. Beranda}

User dapat mencari suatu catatan pekerjaan yang diinginkan dengan menggunakan fitur ini, terdapat filter berupakategori dan lainnya.

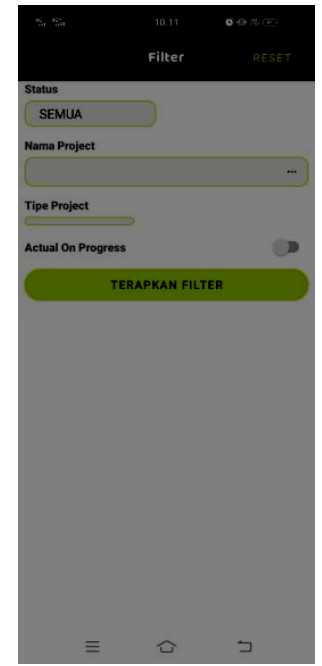


4. Kelola Catatan Kerjaan

\section{Gambar 6. Cari pekerjaan}

Setelah user melihat catatan pekerjaan dan memasukan ke keranjang, berikut tampilan kelola catatan pekerjaan dengan cara edit, simpan dan hapus

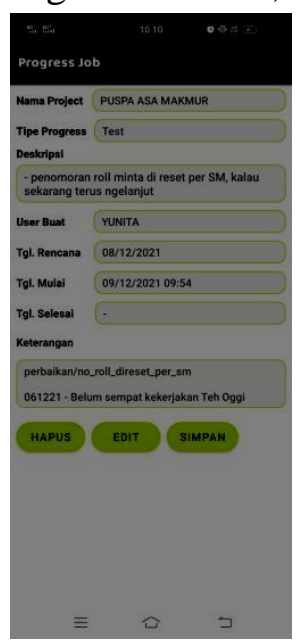

Gambar 7. Kelola

5. Laporan

Seluruh pekerjaan yang dilakukan akan terlihat disini, baik yang berhasil maupun yang tidakberhasil.

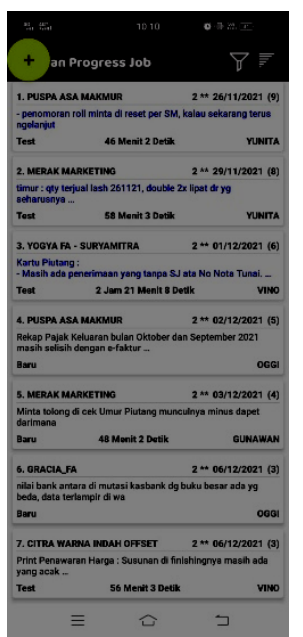

Gambar 8. Laporan

6. Mengurutkan Laporan

Seluruh pekerjaan bisa di order berdasarkan tanggal dari terkecil maupun terbesar 
Gunawan Wirasatya Putra

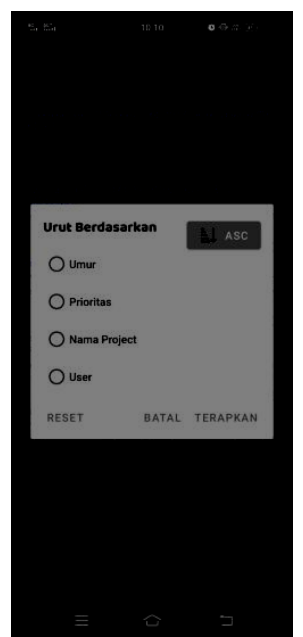

Gambar 8. Order

\section{Kesimpulan}

Dari uraian yang terdapat pada laporan ini, maka penulis menarik beberapa kesimpulan sebagai berikut: 1 . Sistem task manajemen online yang penulis buat sangat memiliki manfaat positif untuk keberlangsungan aktivitas pekerjaan di Orion IT Solution. 2. Sistem yang telah penulis buat dapat menyediakan informasi yang ter-up todate terkait dengan task manajemen yang diinputkan oleh pegawai dan pemimpin. 3. Dengan adanya Sistem Informasi Task Management di Orion IT Solution dapat membantu pimpinan dan pegawainya dalam mengelola proyek yang sedang berlangsung. 4. Dengan adanya Task Management dapat meyimpan data project baru dan juga detail pengerjaannya secara online yang dapat diakses kapanpun dan dimanapun. 5. Dengan adanya Task Management mempermudah komunikasi antar pimpinan dan anggotanya dalam keterkaitan proyek baru 


\section{Bibliografi}

Adani, Muhammad Robith. (2020a). Bahasa Pemrograman Mobile yang Banyak Digunakan.

Adani, Muhammad Robith. (2020b). Mengenal penggunaan API dan contohnya.

Hidayat, Ara, \& Machali, Imam. (2012). Pengelolaan pendidikan: konsep, prinsip, dan aplikasi dalam mengelola sekolah dan madrasah. Kaukaba.

Juansyah, Andi. (2015). Pembangunan aplikasi child tracker berbasis assisted-global positioning system (a-gps) dengan platform android. Jurnal Ilmiah Komputer Dan Informatika (KOMPUTA), 1(1), 1-8.

Kendall. (2010). Tiga Fase dalam Metode Rapid Application Development (RAD).

MUHAMMAD ROBY, SETIAWAN, \& Akhmad, Khudori. (2019). APLIKASI TASK MANAGEMENT SYSTEM KARYAWAN BERBASIS WEB PADA PT. ALMUDATSIR MEDIA KOMUNIKASI PALEMBANG. Universitas Bina Darma.

Noertjahyana, Agustinus. (2002). Studi Analisis Rapid Aplication Development Sebagai Salah Satu Alternatif Metode Pengembangan Perangkat Lunak. Jurnal Informatika, 3(2), 64-68.

O’Dea, S. (2021). (https://www.statista.com/ statistics/272698/global-market-share-heldby-mobile-operating-systems-since-2009).

Pressman, Roger S. (2005). Software engineering: a practitioner's approach. Palgrave macmillan.

Pressman, Roger S. (2012). Rekayasa perangkat lunak.

Runtuwene, Petra David. (2016). PENGEMBANGAN SISTEM ALARM BERBASIS ANDROID. Politeknik Negeri Manado.

Sutarman, Buku. (2012). Pengantar Teknologi Informasi. Jakarta: Bumi Aksara.

Tashia. (2017). Sistem e-Commerce dan Perlindungan Konsumen. 